236

Received: September 27, 2017

Accepted: December 13, 2017
Macedonian Journal of Animal Science, Vol. 7, No. 1-2, pp. 57-61 (2017)

ISSN $1857-6907$

e-ISSN $1857-7709$

UDC: $636.52 / .58 .087 .5: 591.436 .086$

Original scientific paper

\title{
COMPARATIVE STUDY ON THE EFFECT OF DRY EXTRACT OF TRIBULUS TERRESTRIS ON LIVER'S HISTOSTRUCTURE OF GUINEA FOWL AND JAPANESE QUAIL
}

\author{
Matina Nikolova $^{1 *}$, Svetlana Grigorova ${ }^{2}$, Dimo Penkov $^{1}$ \\ ${ }^{1}$ Agricultural University, 12 D. Mendeleev Str., Plovdiv, Bulgaria \\ ${ }^{2}$ Institute of Animal Sciences, Kostinbrod, Bulgaria \\ *dimitrova@hotmail.com
}

\begin{abstract}
A comparative study of the effect of the Bulgarian product Vemo Herb (dry extract of Tribulus terrestris) produced on the histological structure of liver in Guinea fowl (Numida meleagris) and Japanese quail (Coturnix coturnix japonica) was carried out with 2 groups (control and experimental) from both poultry species: 15 Pearl-gray Guinea fowls ( 12 females and 3 males) per group, and 17 Japanese quails - Pharaon breed (13 females and 4 males) per group. The poultry in the experimental groups received $10 \mathrm{mg} / \mathrm{kg}$ body weight/day of the tested additive. The trial lasted 11 weeks ( 1 week of preparatory and 10 weeks of experimental period). It was found that VemoHerb-T in a daily dose of $10 \mathrm{mg} \cdot \mathrm{kg}^{-1}$ body weight causes a high degree of liver fat dystrophy in male and female poultry from both species. There were no significant differences in the liver histological structure between males and females from both species. Significant effect of the additive is observed on body weight in both male and female Guinea fowls, weight of liver in both male and female Japanese quails and liver's histostructure of the two species - being higher in Japanese quails.
\end{abstract}

Key words: extract of Tribulus terrestris; Guinea fowls; histostructure; Japanese quails

\section{КОМПАРАТИВНА СТУДИЈА ЗА ВЛИЈАНИЕТО НА СУВ ЕКСТРАКТ НА TRIBULUS TERRESTRIS ВРЗ ХИСТОСТРУКТУРАТА НА ЦРНИОТ ДРОБ КАЈ БИСЕРКИ И ЈАПОНСКИ ПОТПОЛОШКИ}

Спроведена е компаративна студија за влијанието на бугарскиот производ VemoHerb (сув екстракт од Tribulus terrestris) на хистолошката структура на црниот дроб кај бисерки (Numida meleagris) и јапонски потполошки (Coturnix coturnix japonica) поделени во 2 групи (контролна и експериментална) од двата вида: 15 бисерки од видот Pearl-gray (12 женски и 3 машки) во група и 17 јапонски потполошки од видот Pharaon (13 женски и 4 машки) во група. Живината во експерименталните групи добиваше по $10 \mathrm{mg} / \mathrm{kg}$ телесна тежина / ден од тестираниот додаток. Експериментот траеше 11 недели (1 недела подготвителен и 10 недели експериментален период). Се покажа дека VemoHerb-T во дневна доза од $10 \mathrm{mg} \cdot \mathrm{kg}^{-1}$ телесна тежина предизвикува висок степен на масна дистрофија на црниот дроб кај машките и женските единки од двата вида. Немаше значајни разлики во хистолошката структура на црниот дроб помеѓу мажјаците и женките од двата вида. Значителен ефект на адитивот е забележан врз телесната тежина кај машките и женските единки на бисерките, тежината на црниот дроб кај машките и женските потполошки и хистоструктурата на црниот дроб на двата вида беа поголеми кај јапонските потполошки.

Клучни зборови: екстракт од Tribulus terrestris; бисерки; хистоструктура; јапонски потполошки

\section{INTRODUCTION}

Phytobiotics are an alternative of antibiotics and other allopathic medical preparations, which is largely due to concerns related to bacterial resistance. Phytobiotics are products of plant origin, added to food or drinking water in order to improve the immune status and health condition of animals and humans (Gerzilov et al., 2011; Panda et al., 2009; Machabe et al, 2013; Kocaoglun et al., 2011). Bulgarian dry extract of annual herb Tribulus terrestris (TT), under the trademark VemoHerb-T, 
production of Vemo-99 Ltd company, Sofia, Bulgaria, refers to that group of products. It is rich in biologically active substances: furostanol saponins (mainly protodioscin and protogracillin -55 to $65 \%$ ), tannins (not more than 10\%), flavonoids (rutin - not more than 10\%), glycosides, etc. The extract of TT is of substantial interest from both human and veterinary medicine and from animal husbandry. When applied to humans and animals, it has a proven stimulating effect on general metabolism and sexual function (Grigorova et al., 2007; Kashamov, 2008; Tomova, 1987 etc.). In many Bulgarian and foreign investigations is established that the use of the extract leads to increased reproductive (Semerdjiev et al., 2008; Petkova, 2009; Petkova et al., 2009) and productive performance (Semerdjiev et al., 2008; Valchev et al., 2008) in animals, but especially in poultry (Surdjiska et al., 2005; Akbary and Torki, 2015; Duru and Sahin, 2012 and others).

Prolonged use of biologically active substances from the extract of TT, as well as its application in higher doses could lead to congestion and destruction of vital organs such as the liver, kidneys and gonads. About this problem report authors carried out experiments with poultry and rabbits (Kashamov, 2008; Amirshekary et al., 2015; Abadjieva and Kistanova, 2016).

In our investigations with Japanese quails and Guinea fowls is observed, that the prolonged treatment (more than 6 weeks) with higher doses (over 6 $\mathrm{mg} \cdot \mathrm{kg}^{-1}$ live weight) bring negative effect on the histostructure and the functions of gonads, kidneys and some blood indexes (Nikolova et al., 2015; Christev et al., 2011).

There are no studies in Bulgaria about the influence of the herb on the liver of Guinea fowl $(\mathrm{Nu}$ mida meleagris) and Japanese quail (Coturnix coturnix japonica). What is more, no data is found in the available literature about any negative effect of the high doses of the product in those poultry species.

The aim of the present experiment was to study and compare the effect of Bulgarian phytoproduct VemoHerb-T, produced by Vemo Ltd, Sofia, on the liver status (weight, histological structure) in Guinea fowl and Japanese quail.

\section{MATERIAL AND METHODS}

The study was carried out in the Experimental Center of the Department of Animal Sciences, Agricultural University - Plovdiv, Bulgaria. Twenty six female and six male Pearl grey Guinea fowls and 26 female and 8 male sexually matured Japanese quails from Pharaon breed were included in this experiment. The poultry were randomly divided in two groups - control and experimental (13 females and 3 males per group for Guinea fowls; 13 females and 4 males per group for Japanese quails). Guinea fowls from the both groups were raised on deep litter bedding, in enclosures with open space - free range farming. The both groups were fed the same fodder for breeder Guinea fowls, containing 11.8 MJ metabolizable energy, $17.17 \% \mathrm{CP}, 4.21 \%$ fats and $5.41 \%$ crude fibre. Japanese quails from control and experimental groups were kept in cages and received one and the same diet with the following nutritional characteristics: $18.6 \% \mathrm{CP}$ and $11.5 \mathrm{MJ} \cdot \mathrm{kg}^{-}$

${ }^{1}$ metabolizable energy. The trial lasted 11 weeks (one week preparatory and ten weeks experimental period) The Guinea fowls and the quails from the experimental groups received the Bulgarian product VemoHerb-T supplemented to the drinking water in a daily dose of $10 \mathrm{mg} \cdot \mathrm{kg}^{-1}$ live weight. After the experiment the birds were mortified in accordance with the Directive 2010/6/ EC of the EU Parliament.

Live weight of the Guinea fowls and the quails was measured with OHAUS scales with a precision of $0.01 \mathrm{~g}$ immediately before slaughtering. Liver's weight were measured just after slaughtering and samples for histological examination were collected from the liver of all the poultry. The liver samples (approximately $1 / 1 \mathrm{~cm}$ in size) were taken from the lobus caudatus part and they were immediately put in $10 \%$ neutral formalin and fixed in Bouin's fixative for 24 hours. After the end of fixation, a routine processing of the collected samples was performed. The paraffin slices of liver, 5-7 $\mu \mathrm{m}$ thick, were prepared using a Reichert type microtome and put on glass plates. The samples were stained with hematoxylin-eosin of a histological order. The ready preparations were examined under light microscope HUND (Germany, 2005) and pictures were taken with CANON camera (Japan, 2005).

\section{RESULTS AND DISCUSSION}

Data in Table 1 confirm that statement, i.e. the live weight from the experimental poultry and their liver weight increase in comparison with the poultry from the control group. Live weight increase is particularly pronounced and statistically significant in female Guinea fowl and the liver weight increase in the male quails. 
Table 1

Live weight and weight of liver from Guinea fowls and Japanese quails, treated with Tribulus terrestris dry extract

\begin{tabular}{lcccc}
\hline \hline & \multicolumn{2}{c}{ Guinea fowls } & \multicolumn{2}{c}{ Japanese quail } \\
\cline { 2 - 5 } Items* & Control group & Exp. group & Control group & Exp. grop \\
\hline Live weight - male, g & $1690 \pm 0.02 \mathrm{c}$ & $1870 \pm 0.04 \mathrm{c}$ & $240.67 \pm 6.67$ & $253.60 \pm 9.14$ \\
Live weight - female, g & $1740 \pm 0.04 \mathrm{~b}$ & $1960 \pm 0.05 \mathrm{~b}$ & $314.25 \pm 9.86$ & $318.14 \pm 16.11$ \\
Liver's weight - male, g & $18.79 \pm 7.49$ & $20.20 \pm 10.78$ & $4.34 \pm 0.97 \mathrm{~b}$ & $3.44 \pm 0.40 \mathrm{~b}$ \\
Liver's weight - female, g & $20.51 \pm 3.17$ & $22.08 \pm 3.23$ & $6.12 \pm 0.59 \mathrm{c}$ & $6.55 \pm 0.22 \mathrm{c}$ \\
\hline \hline
\end{tabular}

*Significant in each row: $\mathrm{a}-\mathrm{p}<0.001 ; \mathrm{b}-\mathrm{p}<0.01 ; \mathrm{c}-\mathrm{p}<0.05$

Histological picture of the livers in the experimental poultry showed significant diversity. A part of the liver parenchyma has a structure similar to the birds from the control group (Figure 1). In some of the hepatic lobules, fatty infiltration is observed in the cytoplasm of tubular hepatocytes, located near the central vein of the lobules. Available fatty drops are of different sizes and sometimes they fill the entire cytoplasm of the cells (Figure 2). In other parts of the liver parenchyma, advanced fatty dystrophy

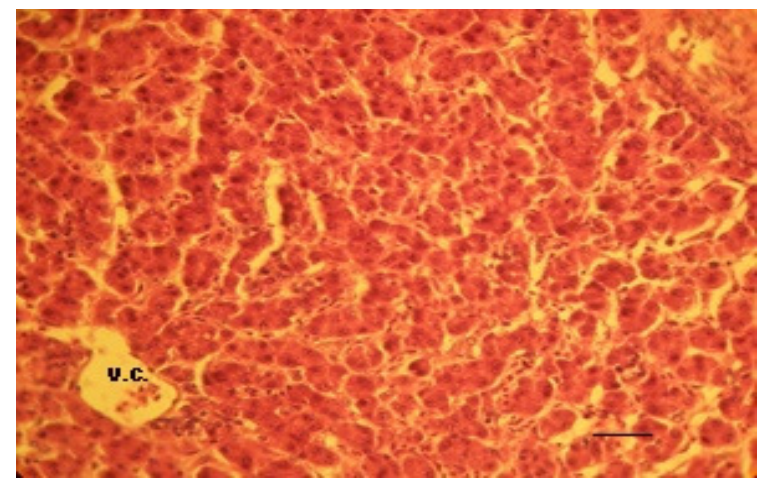

Fig. 1. Liver from male Japanese quail with normal structure, - control group, $400 \times, \mathrm{X} / \mathrm{E}$

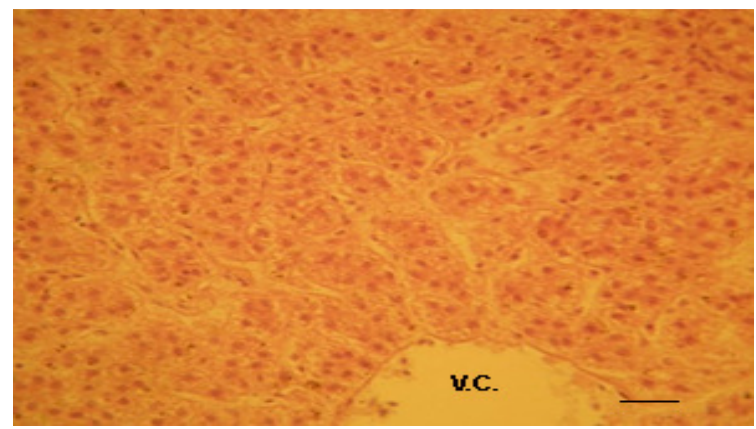

Fig. 2. Liver from female Guinea fowl - control group X/E, $400 \times$ v.c. - central vein. Hepatic cells with pale cytoplasm with fat accumulation is observed, affecting all the hepatocytes in the hepatic tubules. Their cytoplasm is filled with many lipid droplets, different in size. Pyknotic changes in the nuclei occur as a result of the dystrophy (Figure 3). The essential difference in the histological structure of the hepatic parenchyma between the male and female poultry from experimental groups is that the total fatty dystrophy affecting all the hepatocytes in the hepatic trabeculae, is stronger expressed in the male individuals (Figure 4).

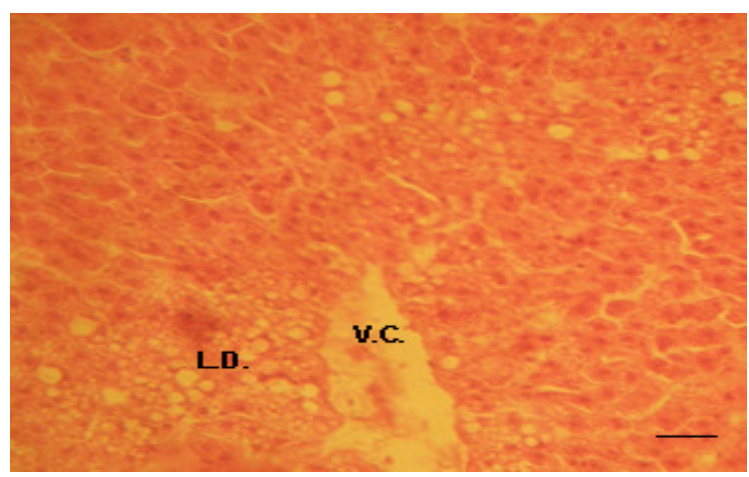

Fig. 3. Liver from female Guinea fowl - experimental group, X/E, 400x. L.D. - fat drops, v. c. - central vein of the hepatic lobule. Hepatic lobule with fat infiltration of part of hepatic cells

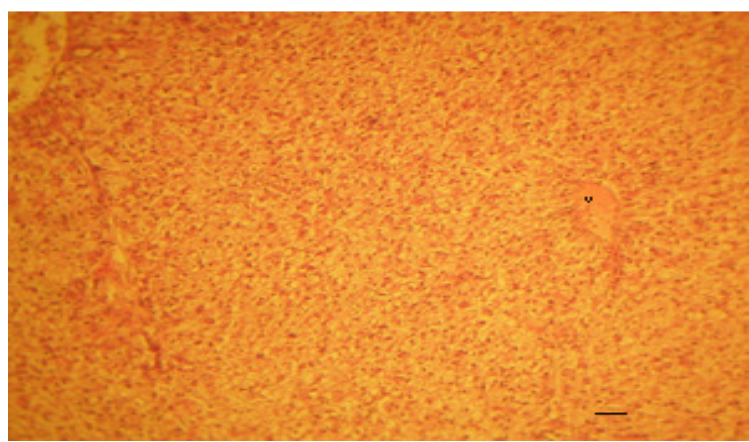

Fig. 4. Liver from male Guinea fowl - experimental group, $\mathrm{X} / \mathrm{E}, 100 \times$. Total fat dystrophy of liver parenchyma 
In the hepatic parenchyma of the male quails from the experimental group there are sections with an unaffected structure, as well as sections with total fatty dystrophy of the hepatic lobules (mosaic structure). The cytoplasm of the affected hepatocytes is filled with lipid droplets of different sizes and their nuclei are pyknotic or completely absent (Figure 5). In the female quails of that group, the major part of the liver parenchyma has a normal histological structure, but there are limited sections with fatty infiltration and dystrophy (Figure 6).

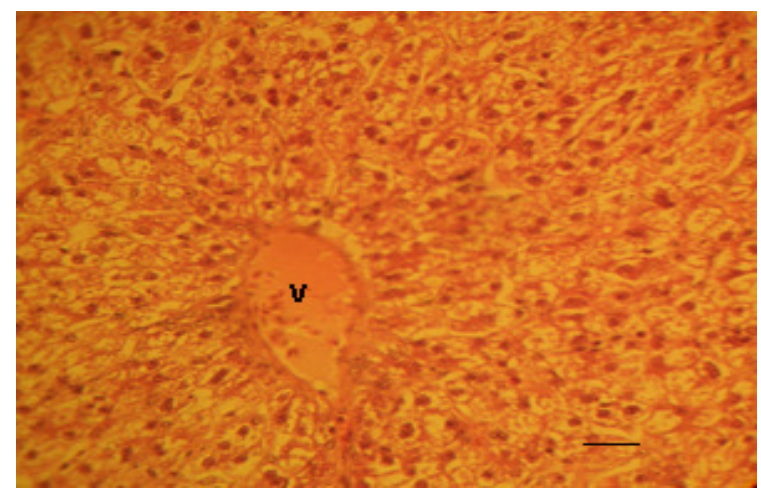

Fig. 5. Liver from male Japanese quail (exp. group), - fat distrophy zone, X/E, 400x

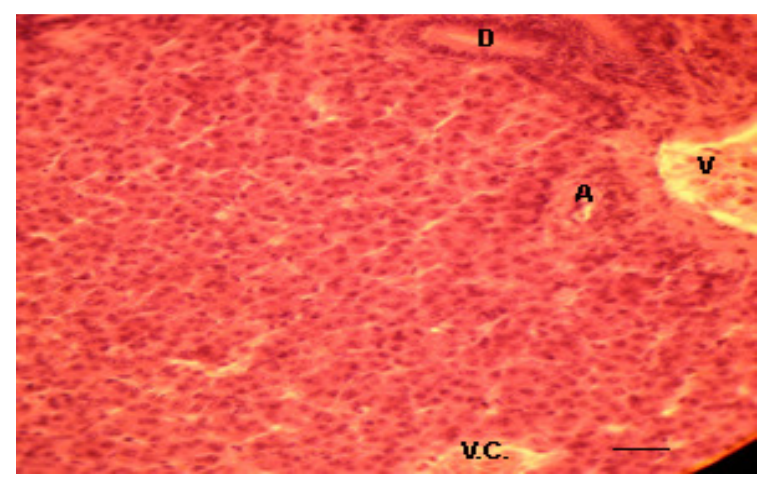

Fig. 6. Liver from female Japanese quail - exp. group - fat distrophy zone, X/E, 400× v. c. - central vein of the hepatic lobule, $v-$ peritubular vein, $\mathrm{a}-$ arteria peritubularis, $d$ - bile duct

Tribulus terrestris has a tonic effect. The main active substances (steroidal saponins from furostanol type protodioscin and protogracilin) contained in the plant, stimulate the production of luteinizing hormone (LH), which in its turn directly affects the production of testosterone (estrogen, respectively). As a result, the strength, muscle growth and the overall activity of the reproductive system are improved.
Despite the positive effect on the reproductive and productive indexes, the adding of Tribulus terrestris in higher doses (more than $6 \mathrm{mg}$ per $\mathrm{kg}$ live weight - in our case $10 \mathrm{mg}$ per $\mathrm{kg}$ live weight) in longer period (over 5 weeks) influences negative on the liver, leading to moderate to high fatty infiltration and liver dystrophy. Our results, by experiments with Guinea fowls and Japanese quails confirm the conclusions of Abadjieva (2015) in experiments with rabbits.

We recommend the adding of Tribulus terrestris as a stimulator in lower doses $\left(4-6 \mathrm{mg} \cdot \mathrm{kg}^{-1}\right.$ $\mathrm{LW}$, or higher dose (but less than $10 \mathrm{mg} \cdot \mathrm{kg}^{-1} \mathrm{LW}$ ) for shorter period (less than 6 weeks).

\section{CONCLUSIONS}

Live weight in poultry from experimental groups and their liver weight increase compared to the control groups. The live weight increase is particularly pronounced and statistically significant in the female Guinea fowl and the increase of the liver weight - in the male Japanese quails.

After treatment of Guinea fowls and quails with dry extract of Tribulus terrestris at a dose of 10 $\mathrm{mg} \cdot \mathrm{kg}^{-1}$ body weight, given for 10 weeks, the birds develop moderate to high fatty infiltration and liver dystrophy, predominantly in the males from the two species.

Taking into consideration the results obtained, we consider the applied dose and the duration of treatment as maximal, however we recommend lower doses and some periods of rest between shorter periods of exposure.

\section{REFERENCES}

[1] Abadjieva, D.: Ozenka na efecta ot biologichno activnine hranitelni dobavki Spirula Pratensis I VemoHerb-T varhu reprodukzijata na jenski sajzi, $\mathrm{PhD}$ thesis, Sofia, p. 185, 2015 (in Bulgarian)

[2] Abadjieva, D., Kistanova, E.: Tribulus terrestris alers the expression of growth differenciation of Factor 9 and bone morphogenic protein 15 in rabbit ovaries of mothers and F1 female offspring, 2016. Plos one / DOI: 10,1371/journal. Phone.0150400.

[3] Akbary, M., Torki, M.: Effects of adding aqueous extract of Tribulus terrestris to diet on productive performance, egg quality characteristics and blood biochemical parameters of laying hens reared under low ambient temperature $\left(6.8 \pm 3^{\circ} \mathrm{C}\right)$, Int. Journal of Biometeorology (2015). DOI: $10.1007 / \mathrm{s} 00484-015-1079-6$

[4] Amirshekari, T., Ziaei, N., Ghoreishi, S., Esfandiapour, E.: The effects of adding aqueous extract and dried aerial part 
powder of Tribulus terrestris on productive performance and blood parameters of laying hens, Journal of Applied Poultry Research (2015), http://japr.oxfordjournals.org

[5] Christev, Cr., M. Nikolova, D. Penkov, R. Ivanova, D. Abadjieva, Sv. Grigorova: Investigation on the effect of Tribulus terrestris extract on the main biochemical and hematological indices of the blood in Guinea fowls, Jour. of Centraleurop. Agric., 12 (1) 16-26 (2011).

[6] Duru, M., A. Sahin: Effects of dietary puncture vine (Tribulus terrestris) powder in different carriers on growth performance, carcass characteristics and blood parameters of broiler chicks, Kafkas Univ. Vet. Fak. Derg, 18 (3), 359365 (2012).

[7] Gerzilov, V., Bozakova, N., Bochukov, A., Penchev, G., Lyutskanov, M., Popova-Ralcheva, S., Sredkova, V.: Influence of the prebiotic salgard and a herb mixture on Peking ducklings in organic poultry production. I. Growth performance and blood biochemical parameters. Biotechnology in Animal Husbandry, 27 (1), 33-43 (2011). DOI: 10.2298/BAH1101033G

[8] Grigorova, S., Kashamov B., Sredkova V., Surdjiiska S., Kurtenkov A.: Effect of Tribulus terrestris extract on semen quality and serum cholesterol content in White Plymouth Rock-mini cocks, Sovremennyï nauchnyï vestnik, $\mathbf{3}$ (5), 13, 11-18 (2007).

[9] Kashamov, B.: Prouchvane na efekta ot dobavkata Tribulus terrestris L. pri ptizi, PhD thesis, Sofia, 2008 pp. 180.

[10] Kocaoglu, B.,: Effects of probiotic and prebiotic (mannanoligosaccharide) supplementation on performance, egg quality and hatchability in quail breeders, Ankara Univ. Vet. Fac Derg, 58, 27-32 (2011).

[11] Machebe, N., S. Ugwu, C. Atu, N-F. Mbunwen: Intake of some biological seeds and root extracts of plants improves fertility and hatchability of turkey eggs, Jour. of Basic and Applied Sci., 9, 1-6 (2013).

[12] Nikolova, M., G. Penchev, S. Grigorova, D. Penkov, Hr. Hristev, I. Koeva: Effect of different concentrations of Tribulus terrestris dry extract on histological structure of gonads and kidneys in Japanese quail, Macedonian J. of Animal Sci., 5, 1, 11-17 (2015).

[13] Panda, A., Rao, R. S., Rafu, M.: Phytobiotics, a natural growth promoter. Poultry International, 48 (7), 10-14 (2009).

[14] Petkova, M.: Animal health and quality of animal products influenced by nutrition: Research experiences in IAS Kostinbrod, Bulgaria, Proceedings. XIII Symposium "Feed Technology". Novi Sad, 2009, pp. 74-89.

[15] Petkova, M., Grigorova, S., Abadjieva, D.: Blood biochemical changes and sperm quality in bulls fed diet supplemented with dry extract from Tribulus terrestris. Book of Abstracts of the $60^{\text {th }}$ Annual Meeting of the EAAP, 2009, Barcelona, Spain, Session 36, Poster 51.

[16] Semerdjiev, V., Yarkov, D., Chobanova, S., Girginov, D., Uzunova, K.: Effect of the plant supplement Xtract on laying performance and egg hatchability in different breeds of chickens, Trakia J. of Sci., 6, 1 26-29 (2008).

[17] Surdjiyska, S., Stoyanov, D., Zlatev, H., Marinov, I., Marinov, K., Stankova, M. (2005): Efect ot prilaganeto na extract ot Tribulus terrestris varhu produktivnostta na roditel brojleri, Ptizevadstvo, 5, 14-15.

[18] Tomova, M.: Tribestan, Farmazija, 37 (6), 40-42 (1987).

[19] Valchev G., Ivanov A., Grigorova S., Zlateva N.: A study on the effect of Tribulus terrestris L. extract as a growth promoter for rabbits. Journal of Animal Science 45 (3): $96-$ 101 (2008). 
